Tạp chí Khoa học và Công nghệ biển T11 (2011). Số 3. Tr 15 - 30

\title{
VỀ NHŨ̉NG CẤU TRÚC THỦY ĐộNG LỰC ĐẶC THÙ GÂY XÓI LỞ-BỒI TỤ TẠI DẢI VEN BỜ NAM TRUNG BỘ
}

\author{
LÊ PHƯớC TRÌNH, BÙI HỒNG LONG, LÊ ĐÌNH MẦU, PHẠM BÁ TRUNG \\ Viện Hải dương học
}

\begin{abstract}
Tóm tắt: Nhũng cấu trúc thủy động lực đặc thù bao gồm các xoáy thuận chiều kim đồng hồ được hình thành và tồn tại trong các vịnh hở (open bays) thuộc dải ven bờ Nam Trung bộ, các phân khu sóng chuyển tiếp trong truờng sóng nhiễu xạ. Nhánh Tây của xoáy là nhân tố quan trọng bậc nhất gây ra tình trạng bồi lấp các cưa, điển hình là cửa Sa Huỳnh, cửa Tam Quan và cửa Đề Gi. Mũi nhô và các chướng ngại vật ven bờ nhu kè mỏ hàn, kè cảng, v.v... , tạo ra truờng sóng nhiễu xạ chứa ba phân khu, trong đó phân khu sóng chuyến tiếp đóng vai trò đặc biệt quan trọng gây nên tình trạng xói lở bờ quyết liệt nhất. Điển hình là bãi biển Phan Thiết và cưm dân cu bờ Nam thị trấn La Gi, noi truờng sóng chịu ảnh huởng của các hệ thống kè cảng. Đó cũng là một trong nhũng nguyên nhân chính gây tình trạng đóng, mở cửa An Hải (đầm Ô Loan).
\end{abstract}

Tù khóa: Nam Trung bộ (NTB), thủy thạch động lực, xoáy thuận, mũi nhô, xói lở-bồi tụ, khúc xạ, nhiễu xạ, hướng Đông Bắc (NE), Đông Đông Bắc (NNE), Tây Nam (SW).

\section{MỞ ĐÀ̀U}

Hệ thủy động lực ven bờ và hình thái bờ Nam Trung bộ (NTB) từ Đà Nẵng đến Bình Thuận mang nhiều nét đặc thù tạo ra những cấu trúc thủy động lực tách biệt và khác biệt nhau, và từ đó là những dạng xói lở-bồi tụ khá điển hình gây ảnh hưởng đáng kể lên cuộc sống các cộng đồng dân cư và hoạt động kinh tế - xã hội ở nhiều địa phương. Thực tiễn đòi hỏi các nhà khoa học phải điều tra-nghiên cứu một cách cơ bản những vấn đề này, cho nên một số đề tài đã được triển khai tại Viện Hải dương học. Bài báo này tổng hợp khía cạnh động lực của các đề tài, chú trọng những cấu trúc thủy động lực cục bộ mang tính đặc thù và cơ chế hình thành chúng, mối quan hệ với những khu bờ bị xói hoặc bồi nghiêm trọng.

Nhân tố bao trùm về không gian và thời gian đối với hệ thủy - thạch động lực dải ven bờ miền Trung bao gồm tác động của các trường sóng bề mặt từ Biển Đông lan truyền vào bờ, của hệ dòng chảy ven bờ được hình thành bởi gió và chế độ địa chuyển trên Biển Đông, tác động của thủy triều và dòng triều ven bờ. Dưới dạng biên cứng nhám và gồ ghề, 
bờ biển tạo ảnh hưởng ngược lại đối với quá trình tác động đó làm thay đổi nhất định cơ chế và hình thái chuyển động của nước biển trong lớp sát bờ. Đặc biệt, những dạng "gồ ghề lớn" và phổ biến như các vũng-vịnh, mũi nhô, kể cả các kè biển, v.v. ... thường tạo ra những cấu trúc thủy-thạch động lực cục bộ khá đặc sắc về khía cạnh khoa học và có ý nghĩa lớn về mặt thực tiễn.

\section{TÀI LIỆU VÀ PHƯƠNG PHÁP}

Bài báo dựa trên những dữ liệu của các đề tài đã được thực hiện gần đây như đề tài "Đánh giá những tác động của các công trình bảo vệ đến môi trường vùng cửa sông ven biển Nam Trungb" (Lê Phước Trình, 2008a). Đề tài "Luận chứng khoa học kỹ thuật phục vụ cho quản lý tổng hợp và phát triển bền vững dải ven bờ biển Nam Trung bộ đáp ứng mục tiêu chiến lược phát triển kinh tế biển" (Lê Phước Trình, 2008b). Đề tài KHCN.06.08 và đề tài hợp tác nghiên cứu với Viện Hải dương học Quốc gia Ân Độ (Lê Phước Trình, 2000; 2008a). Từ các tư liệu lưu trữ về các công trình nghiên cứu xói-bồi, qui luật thủy thạch động lực vùng ven bờ chúng tôi tiến hành phân tích, lý giải nguyên nhân, cơ chế hình thành các cấu trúc thủy động lực đặc thù và ghi nhận những đặc điểm cơ bản tập trung ở một số khu vực điển hình tại dải ven biển NTB.

\section{KẾT QUẢ NGHIÊN CÚU}

\section{Những kết quả nghiên cứu về xói lở-bồi tụ và biến đổi địa hình tại dải ven biển NTB qua khảo sát thực địa}

\section{- Khu vục Của Đại (Hội An):}

Đặc điểm cơ bản của khu vực Cửa Đại là quá trình dịch chuyển cửa sông về phía Nam liên tục hằng năm và đã kéo dài trong nhiều thập niên, tốc độ dịch chuyển trung bình $\approx 50 \mathrm{~m} /$ năm. Biểu hiện của sự dịch chuyển được thể hiện bằng mảng bồi lấp cửa sông bên bờ bắc (phát triển doi cát lấn lòng sông) và dải xói lở bờ sông ở mạn bên bờ Nam (hình 1). Kèm theo, sau mỗi mùa mưa lũ bờ biển của doi cát phía Bắc thường bị xói mòn còn mũi An Lương ở phía nam thì bồi nhanh ra biển. Đã có công trình xây kè đá dọc bờ sông phía Nam cửa nhằm ngăn chặn quá trình dịch chuyển, nhưng kè bị sóng đánh hư hại không phát huy được tác dụng lâu dài.

\section{- Khu vục các cửa Sa Huỳnh (Quảng Ngãi), Tam Quan và Đề Gi (Bình Định):}

Điển hình ở những nơi này là hiện tượng bồi lấp cửa biển. Mũi cát bồi phía Nam cửa, các bãi bồi ngầm và nổi thường xuyên phát triển trong kênh thu hẹp khu vực mặt cắt 
cửa gây cản trở lưu thông thuyền bè ra vào cảng. Lưu ý, ở đây các kênh tự nhiên nối biển (vịnh hở) với đầm nước ngọt hoặc lợ ở bên trong, cảng cá nằm trong đầm. Biểu hiện của quá trình bồi lấp như sau, có một dòng vật liệu đáy ven bờ Tây các vịnh từ phía Nam tràn lên, tụ lại trước cửa và lấn vào kênh, tạo ra những lưỡi cát bồi (ngầm và nổi) xuyên dọc theo kênh chèn ép luồng lưu thông (Lê Phước Trình, 2008a, 2008b; Phạm Bá Trung và cs., 2010). Đã có những kè mỏ hàn xây dài ra biển ở vị trí phía Nam cửa với mục đích ngăn chặn dòng cát dọc bờ tràn lên, tuy nhiên kè lại gây ra những kiểu biến đổi khác của dòng vật liệu cho nên hiện tượng bồi lấp cửa vẫn cứ tiếp diễn.

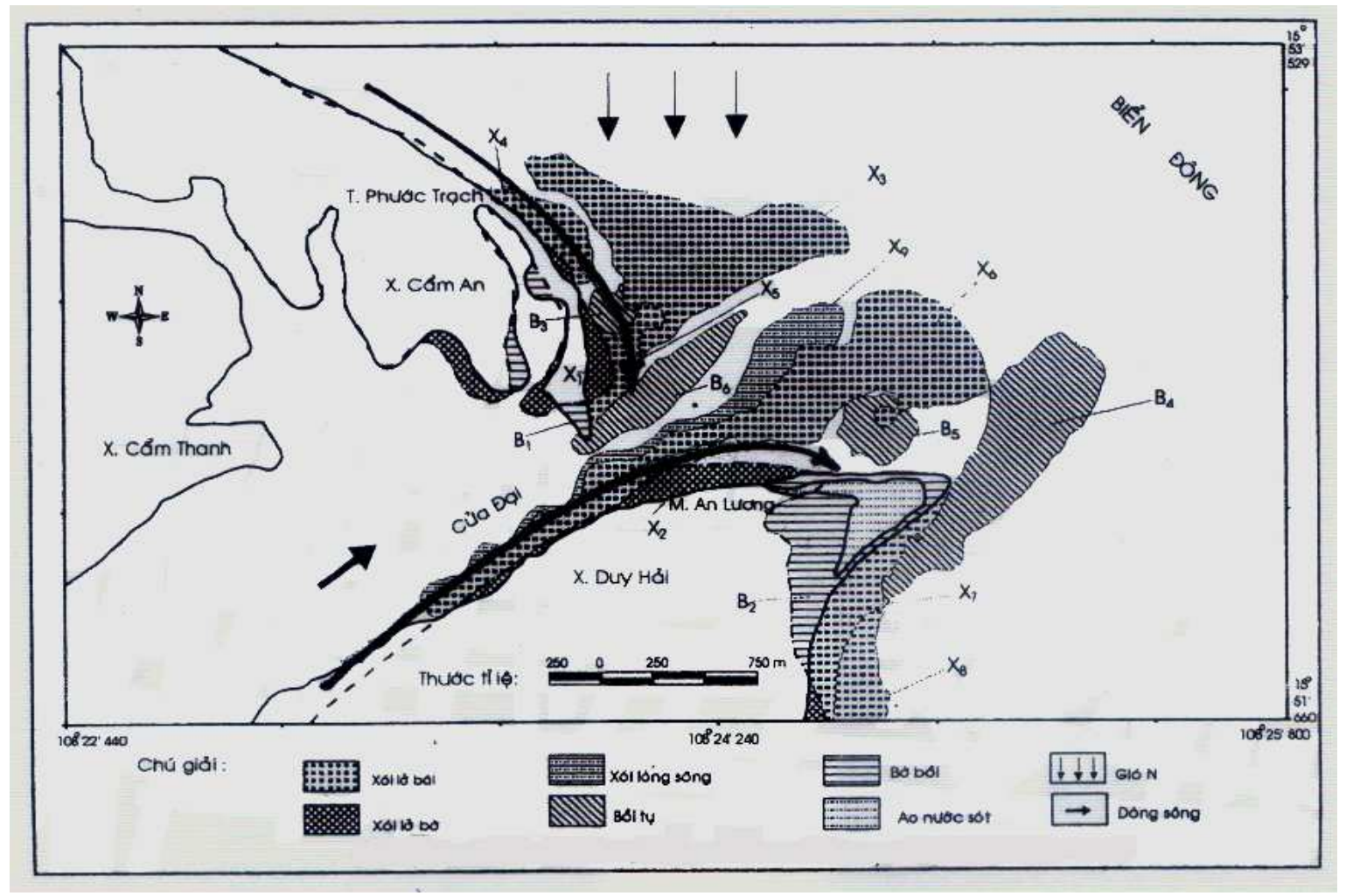

Hình 1: Đặc điểm xói lở-bồi tụ tại Cửa Đại (Hội An)

\section{- Khu vục đầm Ô Loan (Phú Yên):}

Đặc điểm nổi bật nhất là quá trình luân phiên đóng/mở cửa đầm tạo lạch triều cắt ngang doi cát hẹp và dài ngăn cách đầm Ô Loan với biển. Đó là cửa An Hải, thường những năm mưa bão mạnh cửa được mở rồi lại đóng kín (bồi lấp) (Trần Văn Bình, Trịnh Thế Hiếu, 2010; Lê Phước Trình, 2008a). Hiện tượng đóng/mở cửa An Hải gây những khó khăn và thuận lợi nhất định. Khi cửa mở thì thuận lợi cho việc trao đổi nước giữa đầm Ô Loan với biển, thuyền bè của ngư dân vào ra dễ dàng, nhưng lại khó khăn cho sản xuất 
nông nghiệp và các ngành khác do bị xâm nhập mặn. Khi cửa đóng thì đầm bị ngăn cách với biển, hầu như không có lưu thông tự nhiên. Cửa Mái Nhà (Cửa Lễ Thịnh) cạnh mũi nhô ở đầu phía Bắc doi cát không đóng vai trò quan trọng. Hiện tại môi trường nước trong đầm Ô Loan bị xấu đi rất nhiều cần phải được cải tạo, điều đó có liên quan tới cửa An Hải, và đây là vấn đề nan giải của địa phương.

\section{- Khu vục cảng Phan Thiết và cảng La Gi (Bình Thuận):}

Đáng lưu ý nhất là hiện tượng bờ biển bị phá vỡ một cách quyết liệt do tác động sóng trong trường sóng Đông Bắc $(\mathrm{NE})$ sau khi chịu ảnh hưởng từ các hệ thống kè bảo vệ cảng nằm trong cửa sông $C a ̀$ Ty và cửa $\mathrm{La}$ Gi. Cách hệ thống kè cảng chừng $2 \mathrm{~km}$ về phía Nam một khu vực bờ dài chừng 1,5 km bị xói lở cực kỳ mãnh liệt. Bãi tắm của thành phố Phan Thiết và khu dân cư ở bờ Nam thị trấn La Gi bị ảnh hưởng cực kỳ nặng nề, dân buộc phải di dời. Ở đoạn giữa kè cảng và khu xói lở thì, ngược lại, bờ biển ít biến đổi, thậm chí được bồi nhẹ (Lê Phước Trình, 2008b; Phạm Bá Trung và cs., 2010).

\section{Những yếu tố tự nhiên tác động mạnh lên dải ven bờ NTB gây xói lở-bồi tụ}

Những biểu hiện xói-bồi điển hình tuy khác biệt về tính chất và cách biệt về không gian nhưng phần lớn đều có chung những nguyên nhân cơ bản, đó là tác động trên kích thước lớn của trường sóng bề mặt Biển Đông, của hệ dòng chảy ven bờ NTB, một phần do ảnh hưởng của chế độ thủy triều, trong đó sóng và dòng chảy có nguyên nhân từ trường gió.

\section{- Gió và sóng-gió vùng ven bò̀:}

Trên bề mặt Biển Đông chế độ gió thịnh hành là NE (tháng XI-III) và SW (tháng VI-VIII), chúng tạo thành hai trường sóng bề mặt có hướng lan truyền tương ứng. Từ khơi vào bờ, nghĩa là trên dải ven bờ, sự chuyển hướng gió tương đối đồng nhất thành $\mathrm{NNE}$ (mùa đông) và SSW (mùa hè). Nhưng vào sát bờ hướng gió có nhiều thay đổi, cụ thể là về mùa đông từ Đà Nẵng đến Phú Yên gió thống nhất hướng $\mathrm{N}$, sau chuyển thành hướng $\mathrm{NE}$ (Nha Trang) rồi sau đó sang hướng $\mathrm{E}$ (Phan Thiết) (hình 2a). Về mùa hè, tương ứng trong các khu vực ấy là gió $\mathrm{E}$, chuyển thành $\mathrm{SE}$ rồi sau đó là $\mathrm{W}$ (Lê Phước Trình, 2000). Hướng truyền sóng trong dải ven bờ về cơ bản tuân thủ theo sự thay đổi hướng gió (hình $2 \mathrm{a}$ ). Về độ cao sóng, theo tài liệu trong chuyên khảo "Biển Đông" (Nguyễn Mạnh Hùng và cs., 2009) thì độ cao cực đại trung bình năm đạt $6-7 \mathrm{~m}$ trong cung hướng từ $\mathrm{N}$ đến $\mathrm{NE}$ (mùa đông) và 5 - $6 \mathrm{~m}$ cung hướng từ $\mathrm{SE}$ đến $\mathrm{S}$, dọc bờ Bình Thuận là $\mathrm{W}$ (mùa hè).

\section{- Hệ dòng chảy vùng ven bò:}

Hệ dòng chảy trong dải ven bờ NTB là một bộ phận của hệ hòan lưu Biển Đông, hình thành như một cấu trúc luồng Bắc-Nam dọc theo vệt bờ, kích thước không gian và thời gian ổn định (hình 2b; Lê Phước Trình, 2008b). Luồng Bắc-Nam có nguồn gốc từ cân bằng địa 
chuyển và lực căng tiếp tuyến gió, trong lý thuyết tuyến tính thì tốc độ dòng là tổng vec-tơ của hai thành phần đó. Thành phần dòng có nguồn gốc sóng-gió góp phần tăng cường các tính chất vừa nêu của luồng Bắc-Nam, tuy nhiên cấu trúc dòng chảy sóng luôn mang kích thước nhỏ hơn. Về mùa gió $\mathrm{NE}$ cấu trúc luồng Bắc-Nam áp mạnh vào bờ, phần đuôi kéo dài đến tận mũi Cà Mau, cường độ luồng khá mạnh, ở đầu các mũi nhô tốc độ trung bình đạt đến trên $60-70 \mathrm{~cm} / \mathrm{s}$, trước mũi Đại Lãnh tốc độ dòng chảy trên $100 \mathrm{~cm} / \mathrm{s}$ (Cap Varella). Về mùa gió $\mathrm{SW}$ những tính chất đó giảm trong chừng mực nhất định, hướng dòng trong lớp bề mặt đôi khi chuyển thành $\mathrm{N}$ hoặc $\mathrm{N}-\mathrm{NE}$, từ vĩ độ $11.5^{\circ} \mathrm{N}$ (ngang vịnh Phan Rang) luồng tách bờ ra khơi nhường dải ven bờ tỉnh Bình Thuận cho dòng chảy gió có hướng ngược lại (Lê Phước Trình, 2008). Trong bức tranh thủy-thạch động lực cụ thể mang tính địa phương thì qui luật điều hòa của thủy triều và dòng triều chỉ đóng vai trò xúc tác làm tăng hoặc giảm cường độ của những sự kiện tự nhiên đã hình thành hoặc đang xảy ra.

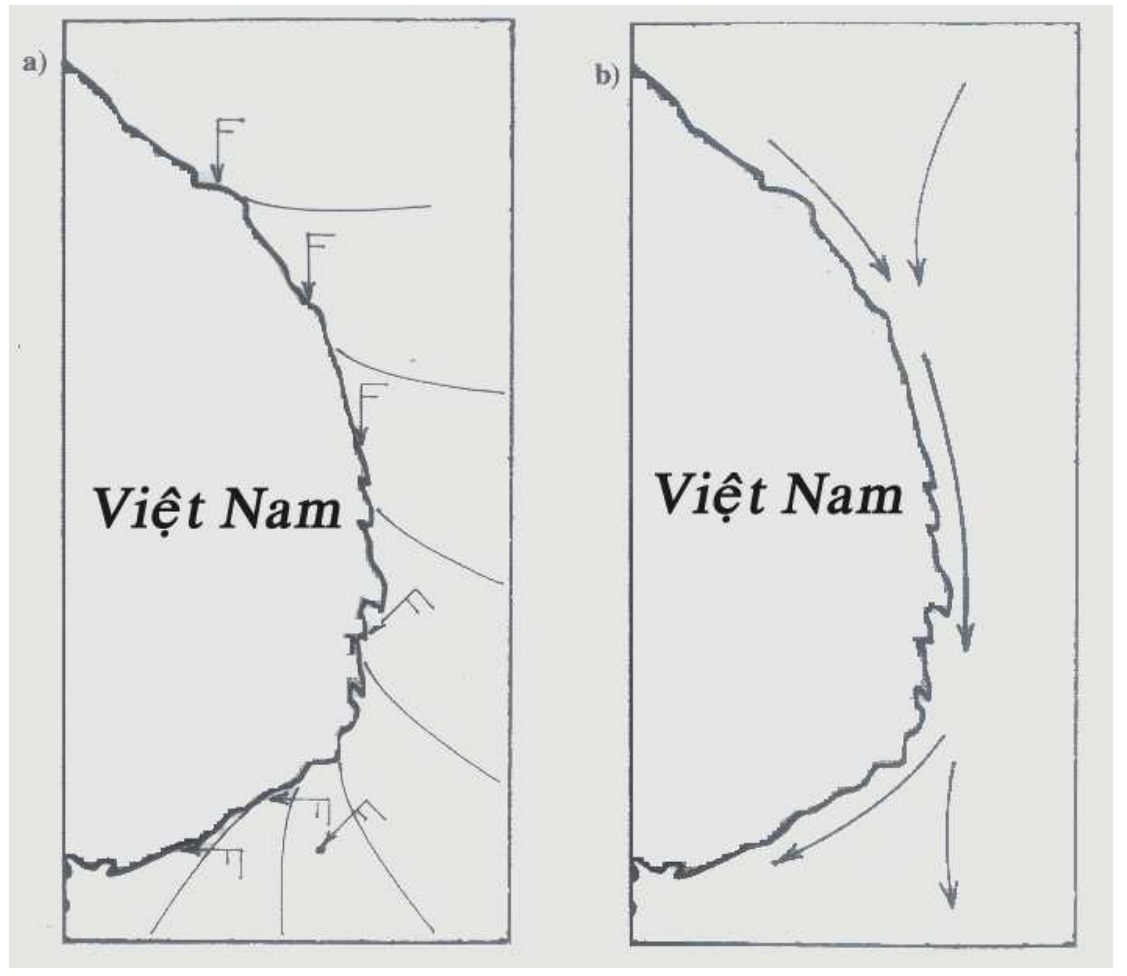

Hình 2: Sơ đồ trường gió và front sóng (a) và hệ dòng chảy ven bờ (b), mùa đông

\section{Hiệu ứng thủy động lực cục bộ và cơ chế hình thành các cấu trúc riêng lẻ}

Hiệu ứng cục bộ là biểu hiện dị thường ở từng địa phương làm biến dạng bức tranh chung mang tính chế độ của chuyển động nước biển trong dải ven bờ. Các dị thường được 
tạo ra bởi ảnh hưởng của biến đổi địa hình bờ kích thước nhỏ hơn kích thước của dải ven bờ, cho nên chúng phụ thuộc chặc chẽ vào đặc điểm hình thái bờ ở từng khu vực.

- Về hình thái bò̀ biển khu vục NTB:

Bờ biển từ Đà Nẵng đến Bình Thuận trên đặc điểm địa hình có thể chia thành hai phần khác biệt. Phần phía Bắc đường bờ ổn định chạy dọc theo kinh tuyến $\left(\sim 109^{\circ} \mathrm{E}\right)$, độ dốc lớn, dải ven bờ sâu, tính chất bờ gồ ghề khúc khuỷu, có nhiều vũng vịnh lớn nhỏ cấu thành từ các mũi đá nhô liền với những dải đất pha cát bằng phẳng. Phần phía Nam đường bờ ổn định chạy theo hướng NE-SW, vật liệu chủ yếu là cát và cát bùn nên độ kết dính không cao, đáy ven bờ nông và thoai thoải, có các vịnh hình cung dài trống trải (Lê Phước Trình, 2008b). Trên nét khái quát đó, ở phần phía Bắc ta lưu ý có nhiều vũng vịnh hở với kích thước chừng $10-15 \mathrm{~km}$ chiều dọc và $4-5 \mathrm{~km}$ chiều ngang, như các vịnh Sa Huỳnh, Tam Quan, Tân Thạnh, Đề Gi, Ô Loan, v.v... . Đoạn bờ phía Bắc các vịnh này thường được cấu tạo bởi những mõm núi đá gốc lớn nhô xa ra biển, đường bờ thẳng hoăc cong lõm vào. Bờ phía Tây liền với các dãy núi đá (thường là cách một con kênh tự nhiên ngắn chừng 200 - 300 mét) và được cấu tạo trên địa hình đồng bằng đất pha cát, phát triển thành bãi biển vòng cung dài chừng $10-15 \mathrm{~km}$. Với cấu tạo như vậy vệt bờ toàn vịnh thường có dáng hình móc câu, phía bờ Bắc vịnh luôn hẳm và bền vững, nhưng ở phía Tây thì là bãi thoai thoải và dễ bị xói lở-bào mòn nhờ đó thường xuyên cung cấp vật liệu cho bồi lấp cửa kênh thông ra biển. Ở phần phía nam (Bình Thuận) ta sẽ lưu ý tới một số công trình kỹ thuật ven biển. Đó là các hệ thống kè chống sóng bảo vệ cảng ở các cửa Phan Rí, Phan Thiết và La Gi. Hệ thống kè có dạng hai đê bê-tông dài vững chải hình gọng kìm xuyên ra biển chừng $1,0 \div 1,5 \mathrm{~km}$ (hình 8 ), có tác dụng như những chướng ngại vật nhân tạo ngăn chặn mọi tác động từ phía biển.

- Lớp biên ngang ven bò̀ và quá trình hình thành chuyển động xoáy cục bộ trong các vịnh hở ven bò::

Cấu trúc luồng Bắc-Nam ven bờ NTB luôn áp sát đường bờ gồ ghề khúc khuỷu, đặc biệt trong mùa gió $\mathrm{NE}$. Ma sát trong quá trình tiếp xúc sẽ tạo ra trong dải sát bờ một lớp biên gọi là lớp biên ngang (horizontal boundary layer). Độ dày mỏng của lớp biên ngang khác nhau tùy từng vị trí và mức độ ảnh hưởng của đặc điểm biến đổi bờ, tính chất chuyển động trong lớp biên đó cũng biến đổi theo một cách tương ứng. Trong lớp biên ngang tính chất rối (turbulent) khống chế chuyển động của nước biển, vì vậy có thể biểu diễn thành phần dọc bờ của tốc độ dòng chảy bằng phương trình Bernoulli : 


$$
w^{2}=\frac{2}{\rho_{0}} P+C
$$

Các ký hiệu: $w$ - tốc độ dòng ; $P$ - áp suất nước ; $\rho_{0}$ - mât độ ; $C$ - hằng số.

Ta dùng một trường hợp cụ thể và phổ biến của vịnh hở ở NTB để xây dựng sơ đồ dòng trung bình trong lớp biên ngang (hình 3), trên sơ đồ biểu thị tập hợp đường dòng và các mặt cắt tốc độ dòng dọc bờ. Lý thuyết thủy động lực cho phép phân tích chi tiết chuyển động trong đó như sau. Theo qui tắc bảo tồn thể tích, dưới ảnh hưởng của mũi nhô địa hình (bờ Bắc và Nam mũi nhô) tập hợp các đường dòng bị dồn ép dần vào bờ từ trước và giản rộng dần ra từ sau đỉnh nhô, bề dày của lớp biên ngang mỏng dần từ trước và dày dần từ sau đỉnh nhô một cách tương ứng. Cùng với biểu hiện đó tốc độ dòng dọc bờ cũng sẽ tăng dần và giảm dần, tức là ở cùng khoảng cách từ bờ thì tốc độ dòng dọc bờ lớn dần lên từ mặt cắt $\mathrm{I}$ (phía Bắc) tới mặt cắt II rồi mặt cắt III (đỉnh nhô), kéo theo là giá trị áp suất nước sẽ nhỏ dần tương ứng (theo định luật Bernoulli). Sau đỉnh nhô, từ mặt cắt III tới mặt cắt IV (nằm bên trong mũi nhô) xuôi theo hướng dòng dọc bờ thì tiến trình hoàn toàn ngược lại, tốc độ giảm dần còn áp suất tăng dần. Như vậy từ mặt cắt III trở về phía Nam nước biển chảy theo hướng tăng áp suất, điều kiện đó buộc phải hãm tốc độ dòng. Trong lớp biên ma sát tình trạng hãm tốc kéo dài cho đến khi tốc độ triệt tiêu (mặt cắt IV).

Tại nơi triệt tiêu dòng ắt phải xảy ra hiện tượng bù trừ nước (compensation) từ phía đối diện, do đó hình thành dòng bù trừ ngược chiều ở phía kia mặt cắt IV. Quá trình bù trừ là quá trình kích thích dòng chảy ở phía bờT vịnh (mặt cắt $\mathrm{V}$ ). Tại mặt cắt $\mathrm{IV}$ xuất hiện đới tụ dòng, tức là một đới mà ở đó xảy ra sự gặp nhau giữa hai luồng dọc bờ đối lập hướng - dòng trong lớp biên ngang từ ngoài vào và dòng bù trừ dọc bờ từ Nam lên. Mực nước tại đây dâng cao hơn bình thường dẫn đến hệ quả tách bờ của hệ dòng chảy, cũng tức là tách bờ của lớp biên ngang truyền thống. Sự kết nối của dòng bù trừ với hệ thống dòng tách bờ chảy về Nam tạo khái niệm rõ ràng về sự khởi động quá trình hình thành xoáy thuận chiều kim đồng hồ ở phần trên của lõm địa hình bờ (vịnh hở). Ban đầu xoáy nhỏ, chưa hoàn chỉnh, áp sát bờ phía đỉnh vịnh. Cơ chế vận chuyển xoáy theo luồng cố định ven bờ $(\vec{u} \Omega=\partial P / \partial n)$ làm cho các xoáy nhỏ tách bờ và dịch chuyển xuôi theo vịnh, nhường không gian sát mũi nhô cho quá trình hình thành một xoáy mới (hình $4 \mathrm{a}$ ). Các xoáy nhỏ chưa hoàn chỉnh tác động lẫn nhau, kết hợp nhau và phát triển thành xoáy kích thước lớn hơn, cho đến giai đoạn dừng thì còn lại chỉ một xoáy hình ê-lip chiếm toàn bộ không gian vịnh và ổn định theo thời gian (hình 4b; Lê Phước Trình, 2008b). 


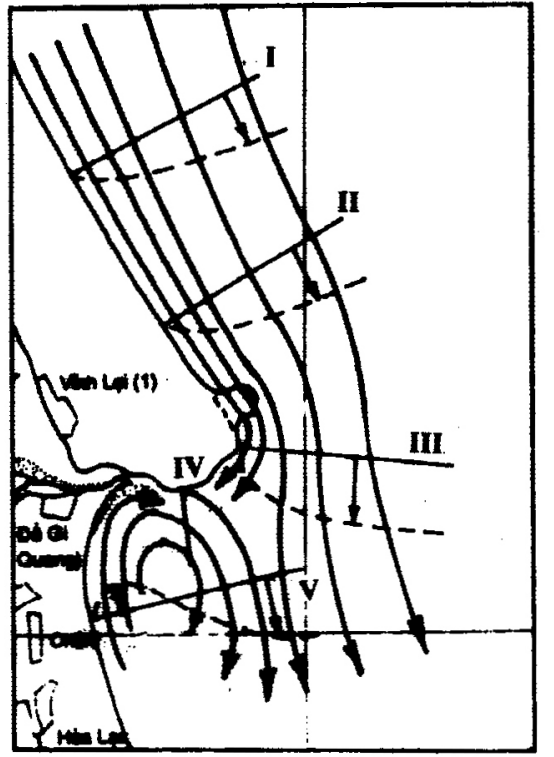

Hình 3: Sơ đồ đường dòng và profile tốc độ dòng trong lớp biên ngang trước mũi nhô

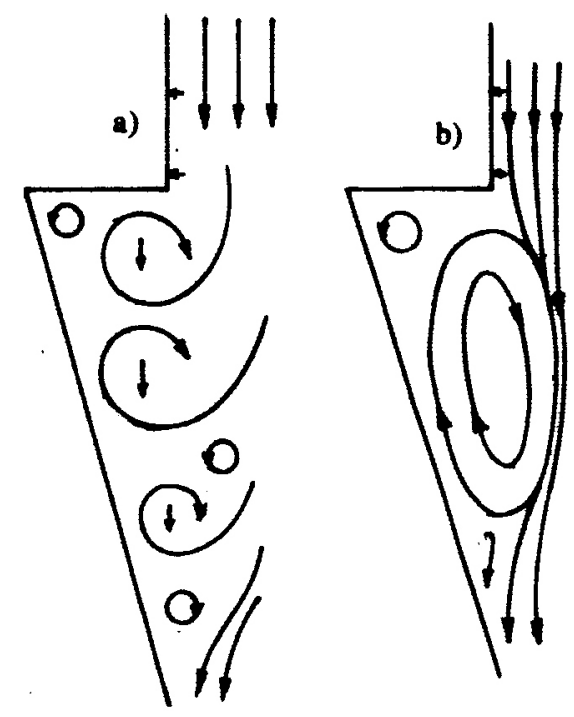

Hình 4: Quá trình hình thành xoáy thuận chiều kim đồng hồ trong các vịnh hở ở giai đoạn phát triển $(\mathrm{a})$ và giai đoạn dừng $(\mathrm{b})$

Trong khoảng không gian vịnh liền sau mũi nhô áp lực nước bị hẩng hụt, gradient áp suất giảm xuống một cách đột ngột và chỉ tăng dần trên mặt cắt cửa vịnh. Điều đó tạo hình thái một lõm thủy lực (hydraulic depression) trên toàn vịnh hở với giá trị cao ở phía đầu vịnh (Lê Phước Trình, 2008b). Nước biển trong không gian liền sau mũi nhô mang tính không bền vững (non-stability), chuyển động loạn với nhiều cuộn xoáy kích thước lớn nhỏ kết hợp nhau.

- Nhiễu xạ sóng sau chướng ngại vật và sụ hình thành nhũng cấu trúc thủy động lục đặc biệt :

Trường sóng vùng ven bờ thể hiện rõ hiệu ứng khúc xạ (refraction), tức là thay đổi hướng truyền của sóng khơi sao cho càng dần vào bờ thì front sóng (wave crest) càng lệch về hướng song song vệt bờ (shoreline), nói cách khác là tia sóng (wave ray) lệch về phía pháp tuyến bờ. Góc lệch front sóng với bờ và góc lệch tia sóng với pháp tuyến bằng nhau (ký hiệu $\alpha_{b}$ ). Sóng tới khi khúc xạ và sóng phản xạ lại từ bờ (reflection) tạo một dải giao thoa ven bờ (interference). Trong lớp biên ngang còn thể hiện hiệu ứng nhiễu xạ sóng (diffraction), tức là biến đổi gấp gáp các qui luật và đặc trưng khúc xạ. Nhiễu xạ đặc biệt rõ khi địa hình biến đổi đột ngột tạo thành những chướng ngại vật chắn ngang các front 
sóng (như kè mỏ hàn, mũi nhô đầu vịnh, doi cát, cồn ngầm, v.v. ...). Đối với vùng ven bờ NTB, mũi nhô đầu các vịnh hở đóng vai trò như những chướng ngại vật khổng lồ ngăn chặn quá trình truyền sóng ở cung độ $\mathrm{N}-\mathrm{NE}$ từ biển khơi vào. Dùng hình thái phổ biến của chướng ngại vật là mũi nhô, trên nguyên lý cơ bản của lan truyền sóng ta xây dựng sơ đồ trường sóng khúc xạ (hình 5 và 8 ), sơ đồ thể hiện các tập hợp front sóng (đường đứt quảng) và tia sóng tương ứng (đường liền). Phân tích sơ đồ có đối chiếu với thực địa (Lê Phước Trình, 2000, 2008a, 2008b) ta rút ra nhận định về những đặc điểm sau:

+ Đặc điểm phân khu tính chất sóng nhiễu xạ sau chướng ngại vật:

Toàn khu vực sóng chịu ảnh hưởng mũi nhô được phân thành ba phân khu khác biệt rõ về tính chất : phân khu $\mathrm{A}$ khuất sóng; phân khu B sóng chuyển tiếp; phân khu $\mathrm{C}$ sóng trở về chế độ khúc xạ truyền thống.

- Phân khu khuất sóng (A) liền sau mũi nhô thật dễ hiểu. Ở đây $H_{b}$ - độ cao sóng giảm đột ngột đến tối thiểu, năng lượng sóng không đáng kể, mặt biển tương đối yên tĩnh, dao động mực nước do sóng (set-up, set-down) rất nhỏ. Ở đây hướng lan truyền sóng chỉ còn phụ thuộc vào nhiễu xạ từ ngoài vào và từ phía Nam lên, front sóng tạo hình xoắn logarít (spiral), góc lệch tia sóng $\alpha_{b}$ nằm về bên phải pháp tuyến bờ.

- Phân khu sóng chuyển tiếp $(\mathrm{B})$ hình thành do quá trình chuyển tiếp trạng thái biển từ khuất sóng (chịu ảnh hưởng tuyệt đối của mũi nhô) trở về khúc xạ truyền thống (kết thúc ảnh hưởng). Quá trình chuyển tiếp thể hiện tính đột biến các đặc trưng sóng cho nên phân khu này hẹp về không gian. Đột biến thể hiện ở hai khía cạnh, một mặt hướng lan truyền sóng thay đổi từ chế độ nhiễu xạ tuyệt đối (A) sang chế độ khúc xạ truyền thống (C), góc lệch $\alpha_{b}$ thay đổi từ bên phải pháp tuyến bờ sang bên trái xuyên qua giá trị $0^{\circ}$, tức là tia sóng trực giao với bờ (orthogonal và gần như vậy), lúc này toàn bộ công suất sóng (power) sẽ dập vào bò̀. Mặt khác, độ cao sóng ở đây tăng đột biến, có thể đến giá trị maximum do front sóng song song vệt bờ. Hai điều kiện thiết yếu là $H$ lớn và $\alpha_{b} \cong 0^{0}$ kết hợp nhau tạo công suất sóng cực mạnh. Đây là đặc tính cực kỳ quan trọng của nhiễu xạ sóng, gây xói lở bờ quyết liệt sau chướng ngại.

- Phân khu khúc xạ truyền thống $(\mathrm{C})$ bắt đầu từ nơi kết thúc hoàn toàn ảnh hưởng của mũi nhô, tức là nơi kết thúc phân khu chuyển tiếp $B$, trường sóng trở về với chế độ khúc xạ ven bờ truyền thống. 


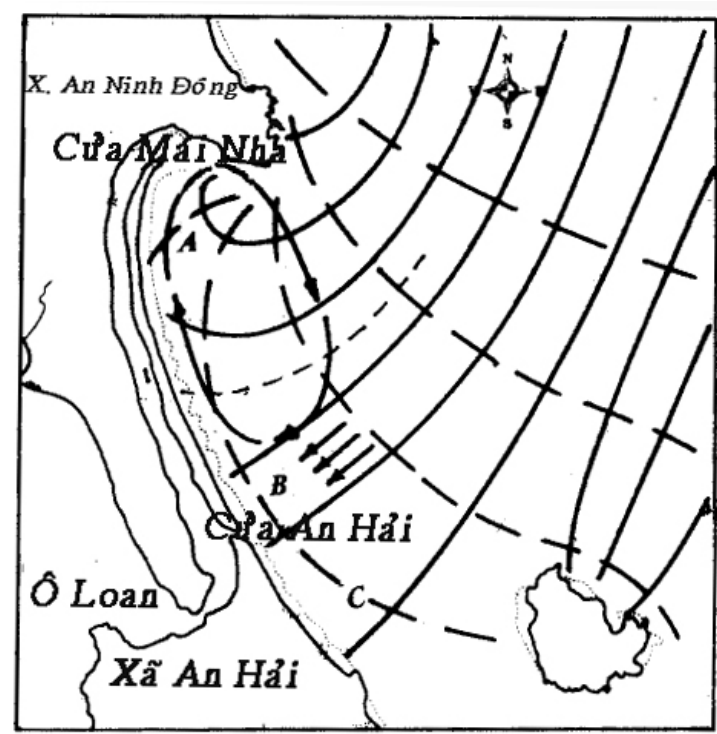

Hình 5: Sơ đồ nhiễu xạ sóng sau mũi nhô ở các vịnh hở

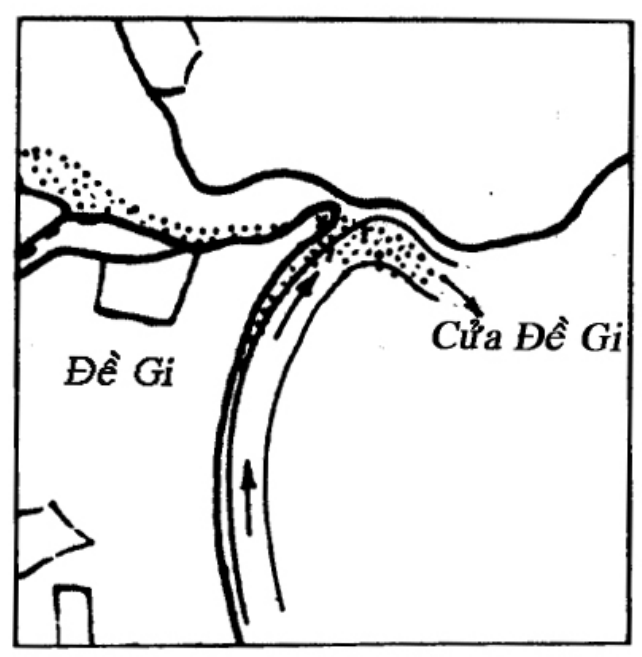

Hình 6: Dải vật liệu bồi tích vịnh Đề Gi và sơ đồ nhánh Tây của xoáy

+ Đặc điểm hình thành chuyển động xoáy nhiễu xạ sau chướng ngại vật :

Chênh lệch độ cao sóng giữa phân khu $(\mathrm{A})$ và phân khu $(\mathrm{B})$ tương đối lớn, dẫn tới chênh lệch mực nước do sóng (set-up) nghiêng về nơi khuất sóng. Độ chênh mực nước là nguyên nhân chính hình thành dòng chảy dọc bờ có hướng từ phân khu $\mathrm{B}$ tới phân khu $\mathrm{A}$. Giá trị tốc độ dòng phụ thuộc giá trị độ nghiêng mặt nước $\left(\gamma \sqrt{g H_{b}}\left(\partial H_{b} / \partial y\right)\right)$, nhưng thường là khá lớn bởi vì khoảng cách giữa hai nơi không xa. Dòng dọc bờ mạnh theo hướng từ phân khu $(\mathrm{B})$ đến phân khu $(\mathrm{A})$ vòng lên đến cuối mũi nhô gây hiệu ứng chảy vòng tròn men theo vệt bờ, đó là nhân tố cơ bản kích thích quá trình thành tạo một xoáy thuận chiều kim đồng hồ trong khu vực. Các nhân tố khác như dòng chảy sóng trước mũi nhô, luồng chảy biển ven bờ, v.v. đóng góp vào quá trình đó. Ta tạm gọi đó là xoáy nhiễu xạ (hình 5), khác về nguồn gốc so với xoáy trong lớp biên ngang (hình 4). Phân khu khuất sóng $(\mathrm{A})$, phân khu sóng chuyển tiếp $(\mathrm{B})$ và xoáy nhiễu xạ là những cấu trúc thủy động lực đặc biệt có ý nghĩa thực tiễn rất lớn.

\section{Một số cấu trúc đặc thù trong chế độ thủy thạch động lực tại dải ven biển NTB và tác dụng thực tiễn}

Những kết quả nghiên cứu trên đối chiếu với những điều kiện tự nhiên cụ thể ở ven bờ NTB cho phép phát hiện và làm sáng tỏ một số cấu trúc động lực cục bộ đã được điều tra-khảo sát tại các địa phương. 


\section{- Tại các vịnh Sa Huỳnh, Tam Quan, Đề Gi, Ô Loan:}

Các vịnh Sa Huỳnh, Tam Quan, Đề Gi, Ô Loan tạo dáng địa hình bờ đồng dạng với sơ đồ trên hình 5 . Chúng đều bắt đầu từ một mũi đá lớn nhô xa ra biển ở phía Bắc làm thành những chướng ngại vật tự nhiên gây ảnh hưởng lên luồng chảy Bắc-Nam và chắn sóng hướng cung độ N-NE về mùa đông. Tại đây sẽ hình thành các cấu trúc đặc sắc sau:

+ Cấu trúc xoáy thuận chiều kim đồng hồ trong các vịnh :

- Về dòng chảy: lớp biên ma sát tồn tại ở đây là điều tất yếu và hậu quả dẫn đến là một xoáy thuận ổn định bao trùm không gian vịnh. Xoáy có hình dạng một ê-lip dài theo hướng Bắc-Nam, rìa phía Nam của xoáy không bền vững do không được giới hạn bởi điều kiện biên ổn định, rìa phía Đông phối dòng với luồng Bắc-Nam (Lê Phước Trình, 2008a).

- Về sóng: hiện tượng nhiễu xạ sóng sau mũi nhô lấn át các tính chất khác của trường sóng trong cung độ $\mathrm{N}-\mathrm{NE}$ và hậu quả dẫn đến xoáy nhiễu xạ thuận chiều kim đồng hồ bao trùm không gian phân khu khuất sóng $(\mathrm{A})$ và một phần phân khu sóng chuyển tiếp (B) (Lê Phước Trình, 2008a, b).

Cả hai quá trình tạo xoáy thuận chiều kim đồng hồ xảy ra cùng thời và trên cùng một không gian vịnh, điều đó củng cố vững chắc giả thuyết về sự tồn tại không tránh khỏi cấu trúc xoáy trong các vịnh Sa Huỳnh, Tam Quan, Đề Gi, Ô Loan, v.v. ... .

+ Dòng Nam-Bắc ven bờ vịnh và vai trò đối với bồi lấp cửa:

Nhánh Tây của xoáy luôn tiếp xúc với bờ vịnh, có nghĩa là tồn tại một dòng chảy dọc bờ theo hướng từ Nam lên Bắc, ổn định theo độ ổn định của xoáy ít nhất là trong cả mùa gió NE. Dòng này mang một lượng vật liệu từ phía Nam lên, vật liệu (đáy và lơ lửng) sẽ tụ lại và lắng đọng ở nơi chuyển hướng dòng, nơi đó thường là cửa của các kênh tự nhiên nối biển (vịnh hở) với các vịnh kín trong đất liền. Thế nên quá trình bồi lấp theo các mức độ khác nhau tại các cửa biển Sa Huỳnh, Tam Quan, Đề Gi và đầm Ô Loan chính là quá trình được tạo ra và duy trì bởi nhánh Tây của các xoáy, hay nói cách khác là bởi dòng Nam-Bắc ven bờ vịnh (Lê Phước Trình, 2008a, b). Đó là một trong những vai trò quan trọng của xoáy thuận chiều kim đồng hồ trong các vịnh.

Chứng minh tính xác thực của kết luận vừa nêu có thể tìm thấy ở nhiều khía cạnh của tư liệu điều tra đo đạc về xói lở-bồi tụ của các đề tài. Lấy thí dụ từ tập bản đồ biến đổi địa hình bờ tỷ lệ 1/100 000 được xây dựng bằng tư liệu viễn thám (Lê Phước Trình, 2000). Ở vịnh Đề Gi tồn tại một dải vật liệu bồi tích men theo luồng dọc bờ từ phía Nam lên vượt qua trước cửa vịnh rồi vòng ra khơi (hình 6). Đó là hình ảnh rõ ràng của dòng vật liệu được tạo ra bởi nhánh Tây xoáy thuận chiều kim đồng hồ trong vịnh (Lê Phước Trình, 2008a, b). Thí dụ khác, tại các vịnh Sa Huỳnh, Tam Quan, Đề Gi từ xưa khá lâu đã hiện 
diện kè mỏ hàn do các cộng đồng dân cư tự nguyện đắp bằng đá tảng ở phía Nam cửa, mục đích là để ngăn chặn dòng vật liệu dọc bờ từ phía nam lên bồi lấp cửa. Trong cả thời kỳ lâu dài kè luôn được gia cố, và gần đây hệ thống kè này được Nhà nước xây dựng lại dài hơn và tương đối kiên cố. Chứng tỏ có một chế độ dòng chảy và dòng vật liệu cố định dọc bờ Tây vịnh thường xuyên đưa vật liệu lên tích tụ tại mỏm phía Nam cửa rồi lan ra bồi lấp cửa. Như đã biết, đó là hệ quả của một phần chuyển động xoáy trong vịnh (Lê Phước Trình, 2008a, b).

Như vậy, trên cơ sở lý thuyết cũng như đối chiếu với tư liệu điều tra-khảo sát ta có thể phát biểu về tính tất yếu hình thành và tồn tại nhiều xoáy thuận chiều kim đồng hồ tại những vịnh hở ven bờ miền Trung nơi có các điều kiện tự nhiên đồng dạng với nội dung trình bày. Sơ đồ các xoáy trên một đoạn Nam Quảng Ngãi - Bắc Bình Định được thể hiện trên hình 7.

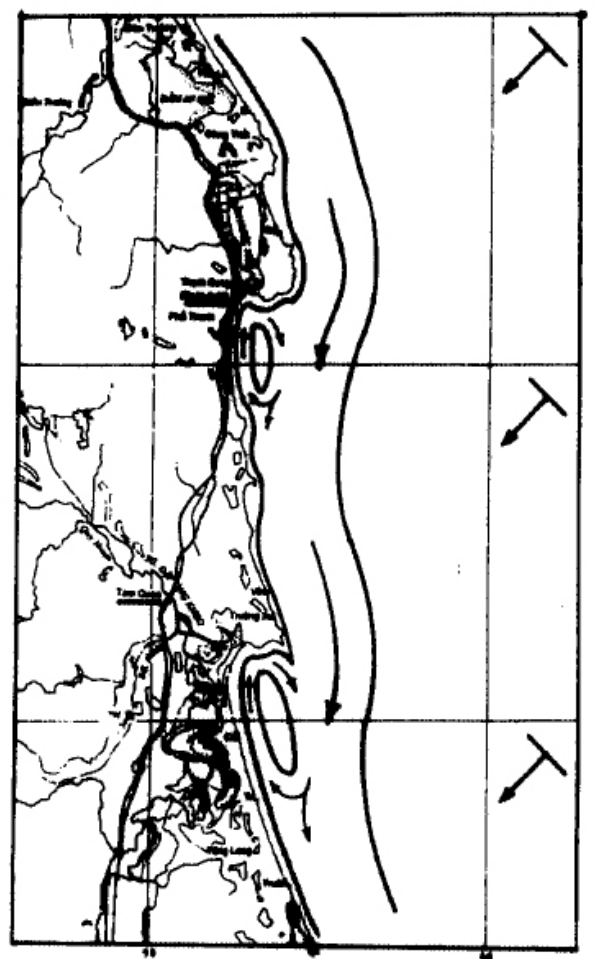

Hình 7: Sơ đồ nhiều xoáy trong các vịnh hở vùng ven bờ NTB (Qủng Ngãi - Bình Định)

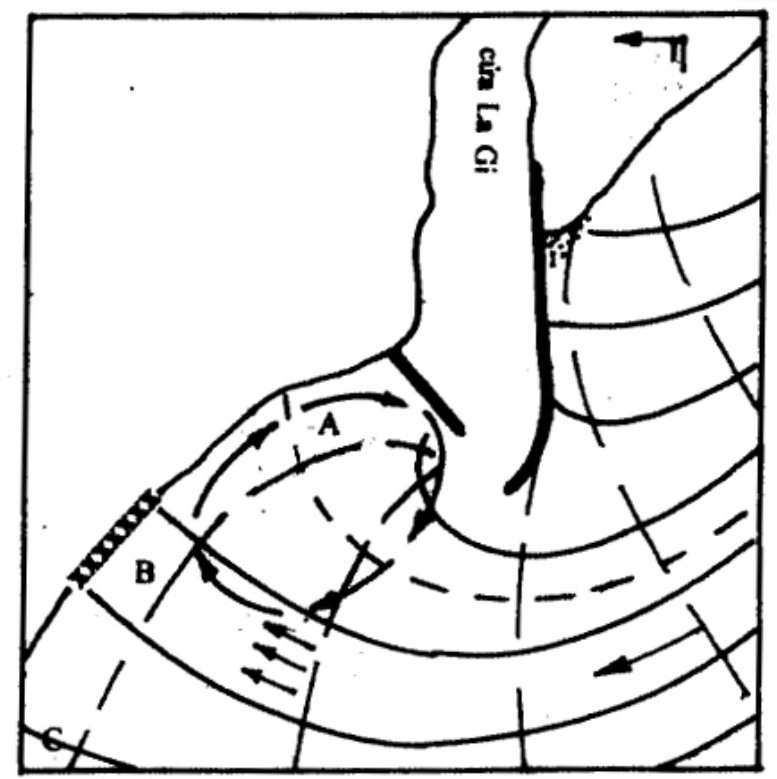

Hình 8: Sơ đồ nhiễu xạ sóng ven bờ do ảnh hưởng của hệ thống kè cảng 
+ Phân khu sóng chuyển tiếp (B) và vai trò chính của nó gây xói lở hoặc phá vỡ bờ quyết liệt ở các vịnh :

Bờ biển tại khoảng giữa bờ cát vòng cung của các vịnh Sa Huỳnh, Tam Quan và Đề Gi luôn có xói lở, qua đó thường xuyên cung cấp lượng vật liệu bồi tích về các cửa. Riêng tại đầm Ô Loan thì doi cát dài phân cách đầm với biển không chỉ đơn giản bị xói lở mà còn bị đánh tan một cách quyết liệt, mở ra cửa An Hải về phía Nam (hình 5). Nguyên nhân chính của các hiện tượng này xuất phát từ phân khu sóng chuyển tiếp $(\mathrm{B})$ được hình thành trong trường sóng hướng cung độ N-NE tại các vịnh.

\section{- Tại của đầm Ô Loan:}

Hình 5 là sơ đồ cơ bản của trường sóng nhiễu xạ sóng nó cũng đã được kết hợp để trình bày trường hợp cụ thể cho địa phương này. Trên khu vực nhiễu xạ sóng sau mũi Mái Nhà sự hiện diện phân khu sóng chuyển tiếp $(\mathrm{B})$ khá nổi bật bởi tập hợp các tia sóng trực giao bờ. Nếu lấy độ cao sóng cực đại ở dải ven bờ NTB $H_{b \max }=6 \mathrm{~m}$ (Nguyễn Mạnh Hùng và cs., 2009) thì tại phân khu (B) dòng năng lượng sóng tác động lên $1 \mathrm{~m}$ đường bờ tương đương 22 Tấn/s - một đại lượng cực kỳ có ý nghĩa đối với vấn đề phá vỡ doi cát để lập thành lạch triều ngay trong giai đoạn đầu của mùa sóng N-NE (ở các vịnh khác thì gây xói lở bờ). Trong trường hợp bình thường, lấy $H_{b}=2 \mathrm{~m}$ thì dòng năng lượng sóng tác động lên $1 \mathrm{~m}$ bờ cũng đến 2,5 Tấn/s. Giáp giới với phân khu này về hai phía $((\mathrm{A})$ và $(\mathrm{C}))$ tình hình không quyết liệt như vậy. Đối với các vịnh khác bức tranh động lực sẽ tương tự. Cù lao Mái Nhà có ảnh hưởng nhất định lên bức tranh lan truyền sóng ở vùng biển bên ngoài Ô Loan, nhưng quan trọng nhất là ảnh hưởng của nó về mùa gió $\mathrm{SW}$ khi mà sóng SE phải vượt qua eo biển rồi mới khúc xạ mạnh vào bờ cận khu vực cửa An Hải. Khi ấy trường sóng khúc xạ sẽ cùng với dòng thủy triều tạo ra quá trình xói ở bờ Bắc và bồi ở bờ Nam lạch triều, đó cũng tức là quá trình dịch chuyển cửa An Hải dần lên phía Bắc doi cát trong chu kỳ năm. Lũ trong đầm Ô Loan cũng tham gia vào quá trình hình thành và dịch chuyển lạch triều An Hải.

\section{- Tại công trình kè chắn sóng cảng Phan Thiết và cảng La Gi:}

Hai cặp kè chắn sóng bảo vệ cảng Phan Thiết và La Gi cũng là các chướng ngại vật ảnh hưởng lên hệ dòng chảy dọc bờ hướng NE-SW và trường sóng hướng $\mathrm{E}$ về mùa gió $\mathrm{NE}$, cơ chế ảnh hưởng giống như trường hợp của các mũi nhô vịnh vừa trình bày trên đây. Trên thực địa quan trắc cho thấy, ở đây trong lúc ảnh hưởng hệ thống kè lên chế độ dòng không rõ rệt thì ảnh hưởng lên trường sóng là cực kỳ mạnh mẽ, các đặc điểm và cấu trúc đã trình bày về trường sóng nhiễu xạ được ghi nhận thậm chí bằng mắt thường. Một đoạn bờ dài chừng 1,5 - 2,0 km sát gốc các kè (phía Nam) ít biến động, thậm chí có bồi nhẹ, 
mặt biển bên ngoài khá yên tĩnh (phân khu A). Liền theo đó thì một đoạn bờ khác cũng chừng $1,5-2,0 \mathrm{~km}$ bị sóng lớn dập rất quyết liệt (phân khu $(\mathrm{B})$ ). Đây là bãi tắm Phan Thiết và khu dân cư nam thị trấn La Gi, bờ biển bị sạt lở nghiêm trọng, dân cư phải di dời. Cuối cùng, tiếp về phía Nam thì tình trạng mặt biển không còn quyết liệt nữa, bờ biển được bồi tụ (Lê Phước Trình, 2008b; Phạm Bá Trung và cs., 2010). Sơ đồ trường sóng nhiễu xạ tại La Gi được trình bày trên hình 8 . Tại Phan Thiết bức tranh tương tự.

\section{- Tại của sông Của Đại (Hội An):}

Hiện tượng dịch chuyển cửa sông Cửa Đại có những điểm cũng gắn liền với những chi tiết của cơ chế vừa trình bày. Về mùa gió $\mathrm{NE}$, dòng chảy tổng hợp (gồm dòng chảy gió và dòng chảy sóng) ven doi cát bờ Bắc khá mạnh và ổn định, tốc độ trung bình đo được trong khoảng $50-70 \mathrm{~cm} / \mathrm{s}$ (Lê Phước Trình, 2000). Đó là nhân tố cơ bản dẫn một lượng cát lớn men theo bờ đưa xuống vùng cửa sông. Ở cuối doi cát, nơi tiếp giáp với dòng sông, dòng tổng hợp ven bờ bị dứt đột ngột, ấy là lý do tất yếu tạo ra một vùng lõm thủy lực áp sát bờ doi cát về phía lòng sông. Các tính chất của lõm thủy lực là điều kiện thuận lợi cho vật liệu lắng đọng và tích tụ, từ đó hình thành một bãi bồi cao dần lên khỏi mặt nước nối dài doi cát xuống phía Nam lấn vào lòng sông. Cùng thời gian đó sóng hướng chính Bắc tràn qua sông trên khoảng không gian mặt cắt cửa, tác động mạnh lên bờ phía Nam gây một đoạn xói lở bờ (hình 1). Bồi ở bờ Bắc, xói ở bờ Nam, đó là quá trình dịch chuyển Cửa Đại, là hệ quả các quá trình động lực dòng chảy và lan truyền sóng ven bờ (Lê Phước Trình, 2000). Tư liệu đo đạc nhiều năm cho thấy mức độ lấn sông của bãi bồi và mức độ xói lờ bờ nam gần tương đương, và bằng khoảng $30-50 \mathrm{~m} /$ năm. Cần nói thêm, trong quá trình đó, tình trạng hẹp lòng sông sẽ làm cho tốc độ dòng sông tăng lên ở chính nơi thoát ra biển, trong lũ đã đo được tốc độ $2,4 \mathrm{~m} / \mathrm{s}$. Luồng mạnh của dòng sông luôn lệch và áp sát về bờ Nam, và đây lại là một nhân tố nữa làm hình thành vùng lõm thủy lực khác ở cuối mũi An Lương (phía biển) tạo điều kiện thuận lợi cho sự lắng đọng và tích tụ vật liệu từ sông ra, nhanh chóng mở rộng bãi bồi mũi An Lương (hình 1).

\section{KẾT LUẬN}

Nội dung của bài báo góp phần làm sáng tỏ một số vấn đề sau đây:

1) Tổng hợp những đặc điểm cơ bản về thủy-thạch động lực ở một số khu vực điển hình trên dải ven bờ NTB, trong đó có hiện tượng dịch chuyển Cửa Đại (Hội An), hiện tượng bồi lấp các cửa biển $\mathrm{Sa} H u y ̀ n h$, Tam Quan và Đề Gi, hiện tượng đóng/mở cửa An Hải (đầm Ô Loan), hiện tượng xói lở bờ quyết liệt do ảnh hưởng các hệ thống kè chắn sóng cảng Phan Thiết và cảng La Gi. 
2) Trên cơ sở lý thuyết lớp biên ma sát và qui luật truyền sóng ven bờ đã phát biểu về tính tất yếu hình thành và tồn tại cấu trúc chuyển động xoáy trong các lõm địa hình (vịnh hở), về hiện tượng phân khu trường sóng nhiễu xạ sau chướng ngại vật các dạng, trong đó nổi lên cấu trúc của một phân khu sóng chuyển tiếp cực kỳ quan trọng tại các vịnh hở mùa gió $\mathrm{NE}$ (phân khu đột biến đặc trưng sóng).

3) Nêu giả thuyết về sự tồn tại xoáy thuận chiều kim đồng hồ hình ê-lip bao trùm diện tích các vịnh Sa Huỳnh, Tam Quan, Đề Gi và Ô Loan mà nhánh Tây của chúng chính là nguyên nhân cơ bản ổn định gây ra hiện tượng bồi lấp các cửa biển, gây trở ngại cho các ngành khai thác biển khu vực. Trình bày quan điểm về nguyên nhân phá vỡ bờ cực kỳ nghiêm trọng sau các hệ thống kè cảng Phan Thiết và La Gi cũng như hiện tượng đóng mở cửa An Hải (đầm Ô Loan), đó chính là tác động cực kỳ quyết liệt của phân khu chuyển tiếp sóng nhiễu xạ sau kè và sau các mũi nhô tự nhiên. Về hiện tượng dịch chuyển Cửa Đại hằng năm, đó là hệ quả của quá trình động lực thông qua mối liên hệ giữa sự hình thành bãi bồi mới trong lõm thủy lực cuối doi cát bờ Bắc và quá trình xói lở bờ sông phía Nam do tác động của trường sóng $\mathrm{N}$. Tất cả đều xảy ra hầu như trong mùa gió NE.

Lời cảm ơn: Các tác giả chân thành cám ơn các đồng nghiệp tại phòng Vật Lý biển và phòng Địa chất-Địa mạo biển (Viện Hải dương học) đã nhiệt tình cung cấp tư liệu và động viên trong quá trình hoàn thiện bài báo.

\section{TÀI LIỆU THAM KHẢO}

1. Lê Phước Trình (chủ biên), 2000. Nghiên cứu qui luật và dự đoán xu thế bồi tụ-xói lở vùng ven biển và cửa sông Việt Nam - Báo cáo khoa học tổng hợp Đề tài KHCN.06.08, Chương trình khoa học cấp Nhà nước KHCN.06, 88 tr.

2. Lê Phước Trình, 2008a. Tác động của các kiểu kè mỏ hàn và vấn đề chống bồi lấp ở các cửa biển $\mathrm{Sa}$ Huỳnh, Tam Quan và Đề $\mathrm{Gi}-\mathrm{B} / \mathrm{c}$ chuyên đề. Đề tài "Đánh giá những tác động của các công trình bảo vệ đến môi trường vùng cửa sông ven biển Nam Trung bộ", Chủ nhiệm : TS Lê Đình Mầu, Viện HDH, 45 tr.

3. Lê Phước Trình, 2008b. Hiện trạng xói lở-bồi tụ và tác động của các công trình bảo vệ vùng ven biển-cửa sông miền Trung (từ Đà Nẵng đến Bình Thuận) - B/c chuyên đề. Đề tài "Luận chứng khoa học kỹ thuật phục vụ cho quản lý tổng hợp và phát triển bền vững dải ven bờ biển Nam Trung bộ đáp ứng mục tiêu chiến lược phát triển kinh tế biển", Chủ nhiệm đề tài : TS Bùi Hồng Long, Viện HDH, 47 tr.

4. Nguyễn Mạnh Hùng, Đỗ Thiền, Trương Trọng Xuân, 2009. Trường sóng trên Biển Đông - Trong chuyên khảo "Biển Đông", T. II, Hà Nội: 341-365. 
5. Phạm Bá Trung, Lê Đình Mầu, Lê Phước Trình, 2010. Vấn đề bồi lấp ở các cửa biển Sa Huỳnh, Tam Quan và Đề Gi do tác động của các kiểu kè mỏ hàn. $\mathrm{T} / \mathrm{c}$ KH\&CN Biển, Số 2: 1-13.

6. Trần Văn Bình, Trịnh Thế Hiếu, 2010. Sự biến đổi hình thái địa hình bãi và đường bờ tại một số khu vực bờ biển Nam Trung bộ theo thời gian (2007 - 2008). T/c Khoa học \& Công nghệ biển, T 10: 15-29.

\section{THE SPECIFIC HYDRO-DYNAMICAL STRUCTURES CREATED MAIN EROSION-ACCRETION POINTS ALONG SOUTHERN CENTRAL VIETNAMESE COAST}

\section{LE PHUOC TRINH, BUI HONG LONG, LE DINH MAU, PHAM BA TRUNG}

Summary: Specific hydro-dynamical structures include the clockwise ellipsoid eddies covering the whole open bays of central coastal zone and the narrow zones of diffraction-wave ray orthogonals constructed after changing over large promontaries and harbour breakwaters. First of them is main reason created important mouth accretion points in the bays of Sa Huynh, Tam Quan and De Gi, and the other created most violent collaption points of the coasts of Phan Thiet, La Gi and O Loan.

Key words: Southern Central Vietnamese Coast (NTB), Hydro-litho-dynamic, Anticlockwise eddy, Headland, Erosion-Accretion, Refraction, Diffraction, North--East (NE), North-North East (NNE), South- West (SW).

Ngày nhận bài: 15 - 10 - 2010

Ngườ nhận xét: TS. Trịnh Thế Hiếu 